\title{
PHYTOCHEMICAL ANALYSIS AND EVALUATION OF ANTIBACTERIAL ACTIVITY OF TOKAR SHA
} AGAINST ENTERIC BACTERIA

\author{
*1Shitu, S., ${ }^{1}$ Attahiru, M. and ${ }^{2}$ Iliya, F. A. \\ ${ }^{1}$ Department of Applied Biology, College of Science and Technology, Kaduna Polytechnic, Kaduna State, Nigeria \\ ${ }^{2}$ Department of Pharmacology and Toxicology, Faculty of Pharmaceutical Sciences, Usmanu Danfodiyo University, Sokoto, \\ Nigeria \\ *Corresponding Author's E-mail: $\underline{\text { sabiushitu22@gmail.com }}$

\begin{abstract}
The antibacterial activity of Tokar sha; a local traditional medication widely used by many people in North-west zone of Nigeria especially Sokoto, Kebbi and Zamfara against enteric infections were examined against some clinical isolates of pathogenic bacteria (Staphylococcus aureus, Escherichia coli, Bacillus cereus and Salmonella typhi) using agar well diffusion method. The pattern of inhibition varied with the tokar sha concentrations and the organisms tested. The tokar sha was more effective on E. coli with a maximum zone of growth inhibition of $25 \mathrm{~mm}$ at $35 \mathrm{mg} / \mathrm{ml}$ followed by B. cereus (20mm). However, $S$. aureus and $S$. typhi were resistant to tokar sha at all concentrations tested. The minimum inhibitory concentrations (MIC) were found to be $35 \mathrm{mg} / \mathrm{ml}$ for both E. coli and B. cereus. The antibacterial activities exhibited by tokar sha in this study could be attributed to the presence of its constituents which signifies the potential of the tokar sha as a therapeutic agent. These findings may justify the ethnomedicinal use of tokar sha as an antibacterial agent against enterobacteria.
\end{abstract}

Keywords: antibacterial activity, Escherichia coli, pathogenic bacteria, Tokar sha

\section{INTRODUCTION}

Plants have been classified as an essential source of medicinal agents for centuries and a huge number of novel drug components have been isolated from natural plant sources. Many of these plants and their extracts were used in traditional medicine. Medicinal plants play a key role in health care with about $80 \%$ of the world's population relying on the use of traditional medicine which is predominantly based on plants (Owolabi et al., 2007). Plant-derived medicines have been used due to the significant healing power of the traditional medicinal systems (Adebolu and Oladimeji, 2005). Medicinal plants are distributed worldwide but they are most abundant in tropical countries (Naqvi et al., 1991; Elvin-Lewis, 2001). The abundance of medicinal plants in nature and the traditional knowledge increase the understanding of the medicinal plants' properties, safety and efficacy (Nascimento et al., 2000). This concern has been expressed because of the resistance of clinically pathogenic microorganisms to the antibiotics that have been produced in the last decades (Cohen, 1992; Nascimento et al., 2000). In the last decade, studies based on extraction of biologically active compounds from plant species used for medicinal purposes are intensively increased (Nascimento et al., 2000; Rios and Recios, 2005). In Nigeria, traditional medicine is well acknowledged and established as a viable therapeutic alternative (Kafaru, 1994), and almost all plants seem to have some kind of application in traditional medicine (Babayi et al., 2004). Searches for substances with antimicrobial activity in plants are frequent, due to their popular use as remedies for many infectious diseases (Shibato et al., 2005). Plants are rich in different types of secondary metabolites, such as tannins, terpenoids, alkaloids, and flavonoids, which have been found in vitro to have antimicrobial properties (Cowan 1999; Lewis 2006). Consequently, the development of drug resistance in human pathogens against commonly used antibiotics has necessitated a search for new antimicrobial substances from other sources including plants (Erdogrul et al., 2002). Today, it is estimated that relatively $50 \%$ of Western drugs have plant materials (Rodders et al., 1996). Traditional medical practitioners in Nigeria use herbal preparations to treat microbial infections such as typhoid and Para-typhoid infections and they claimed that the primary benefit of using plant-derived medicines is relatively safer than synthetic alternatives, offering profound therapeutic benefits and more affordable treatments. Several workers have conducted ethnobotanical surveys among various tribes of the African continent and some other parts of the world (Osowole et al., 2005) in search of plants with antibacterial, antiviral and antifungal properties. The medicinal values of these plants lie in some chemical substances which produce a definite physiological action on the human body (Erdogrul et al., 2002).

Tokar sha or sabulun toka is a traditional medicine that is found mainly in the northwest zone of Nigeria specifically Sokoto, Kebbi and Zamfara. Tokar sha is made from millet stalk ash and palm oil which are mixed to make a paste then heat to boil and then cooled to solidify. Tokar sha is used in 
the management of cold, malaria, stomach-ache, abdominal cramp, pile, dyspepsia, epilepsy (Traditional medicinal practitioner). These properties led to the study of its antibacterial property (mainly enteric bacterial).

Bacterial infection has become the most prevalent infectious disease, several semi-synthetic and synthetic drugs are available in practice. However, their effectiveness is affected by their side-effect, contra-indications in children and pregnant women and also rising prevalence of antibiotics resistance of pathogenic microorganisms. This spread of antimicrobial resistance in developing countries including Nigeria is associated with complex and interconnected factors, such as excessive and unnecessary prescribing of antimicrobials, increased self-prescribing by people and poor quality of available antimicrobials (Yadesa et al.,
2015). This antibiotic resistant pathogenic microorganism raises the demand for finding new alternative antimicrobials agents which have the potential of treating bacterial infections with lesser side effects compared to synthetic drugs.

Although this study is novel, since no research have been done on tokar sha but from the Ethnomedicinal survey. It was said to have been used in the treatment of bacterial infection, malaria, cold, epilepsy and related neurologic illness, syphilis, pile, abdominal pain, and cancer, dandruff, and is also used as tooth wash powder, bathing soap and so on. Therefore, this study is aimed at analyzing the phytochemical content and evaluating the antibacterial effect of tokar sha using enteric bacterial (enterobacter).

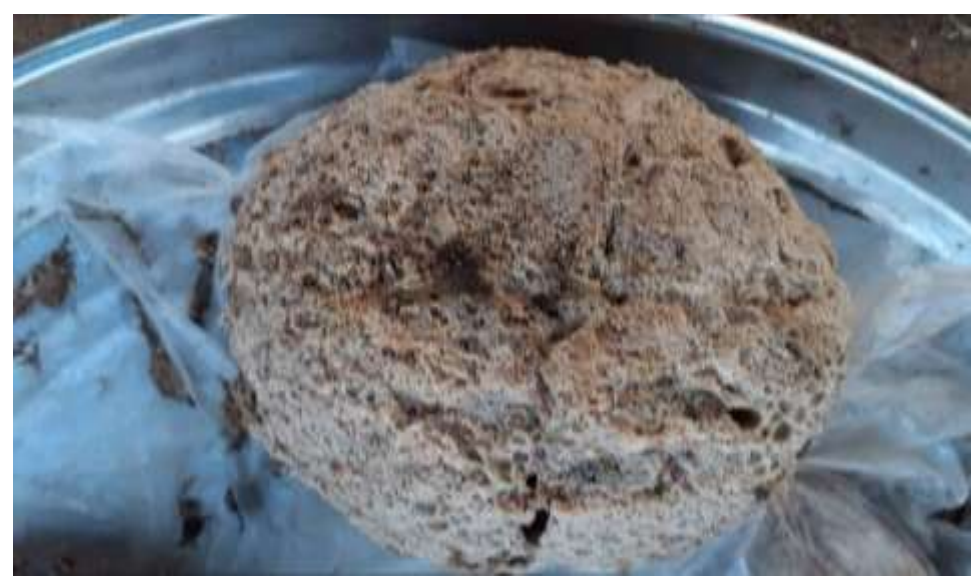

Fig. 1: Tokar sha

\section{MATERIALS AND METHODS}

\section{Culture organisms}

Clinical isolates of two Enteric Gram-positive (Staphylococcus aureus and Bacillus cereus) and two Enteric Gram-negative (Escherichia coli and Salmonella typhi) organisms were used. The bacterial strains were provided by the Microbiology Unit of the Department of Applied Biology, College of Science and Technology, Kaduna Polytechnic, the four (4) bacteria were used, they include; two Enteric Gram-positive bacteria (Staphylococcus aureus and Bacillus cereus) and two Enteric Gram-negative bacteria (Escherichia coli and Salmonella typhi). The choice of these species was based on their availability and to verify the claim of ethnomedicinal use by Traditional Medical Practitioners in the treatment of stomach problems and piles. Sample collection

The sample of tokar sha was collected from a traditional seller from Kofar Gawo, Central market, Sokoto State, Nigeria in October 2019.

\section{Sample preparation}

The collected tokar sha was ground to powder using mortar and pestle. A total of $0.04 \mathrm{~g}, 0.05 \mathrm{~g}, 0.06 \mathrm{~g}$ and $0.07 \mathrm{~g}$ was weighed into a small beaker and $2 \mathrm{ml}$ of distilled water was added to each beaker to make and aqueous solution of 20 $\mathrm{mg} / \mathrm{ml}, 25 \mathrm{mg} / \mathrm{ml}, 30 \mathrm{mg} / \mathrm{ml}$ and $35 \mathrm{mg} / \mathrm{ml}$ respectively and a glass rod is used to stir the solution until a homogeneous mixture is formed since Tokar Sha is completely soluble in water and a foil paper is used to cover the solution to avoid any contamination. Another $0.42 \mathrm{~g}$ was weighed and dissolved in $12 \mathrm{~mL}$ of distilled water making a solution containing $35 \mathrm{mg} / \mathrm{ml}$ and a beaker containing the solution was covered using a foil paper to avoid contamination.

\section{Experimental Animals}

Male and female mice weighing between 19 to $30 \mathrm{~g}$ were purchased from the faculty of Pharmaceutical Sciences, Ahmadu Bello University Zaria. The animals were housed in well-ventilated cages in the animal house of the Department of Applied Biology, College of Science and Technology, Kaduna Polytechnic, Kaduna. The mice were allowed to 
acclimatize for four weeks before the experiment and had access to food and clean water. Principles of laboratory animal care and ethical guidelines for the investigation of experimental pain in conscious animals were observed during experimentation.

\section{Test organisms}

Aqueous solution of $20 \mathrm{mg} / \mathrm{ml}, 25 \mathrm{mg} / \mathrm{ml}, 30 \mathrm{mg} / \mathrm{ml}$ and 35 $\mathrm{mg} / \mathrm{ml}$ of tokar sha were tested against a set of four (4) bacteria.

\section{Media preparation}

The media used were prepared in accordance with the manufacturer's specification and autoclaved at $121^{\circ} \mathrm{C}$ to ensure their sterility as follows;

\section{Nutrient agar}

Nutrient agar powder (11.2 g) was suspended in $400 \mathrm{ml}$ of purified water in the conical flask. The mixture was heated with constant stirring till all the components were fully dissolved. It was autoclaved at $121^{\circ} \mathrm{C}$ for 15 minutes, allowed to cool and $20 \mathrm{ml}$ each was dispensed into 20 sterile Petri dishes and left to solidify.

\section{Nutrient broth}

Double strength nutrient was prepared by weighing nutrient broth powder $(1.3 \mathrm{~g})$ into a conical flask and $100 \mathrm{ml}$ of distilled water was added to it. It was properly mixed and 5 $\mathrm{ml}$ each was dispensed into 8 test tubes.

Staphylococcus aureus, Bacillus cereus, Escherichia coli and Salmonella typhi single strength nutrient broth was prepared following the same procedure using the powder $(2.6 \mathrm{~g})$ in a distilled water $20 \mathrm{ml}$. A $5 \mathrm{ml}$ each was dispensed into 22 test tubes and autoclaved at $121^{\circ} \mathrm{C}$ for 15 minutes.

\section{Preparation of inoculums}

Inoculum of the isolates was standardized by comparing their turbidity with that of $0.5 \mathrm{McF}$ arland standard.

PHYTOCHEMICAL SCREENING OF TOKAR SHA

The fraction of the aqueous solution of Tokar sha was subjected to phytochemical screening as described below.

\section{Test for Tannins}

Ferric chloride test: $1 \mathrm{ml}$ of the extract was diluted with few drops of solution of ferric chloride were added. The appearance of blue-black colour indicates the presence of tannins (Trease and Evans, 2008).

Lead sub acetate test: To $1 \mathrm{ml}$ of the extract 2 drops of lead sub acetate solution were added. A coloured precipitate indicates the presence of tannins.

\section{Test for Alkaloids}

About $5 \mathrm{ml}$ of the $2 \%$ hydrochloric acid was used to dissolve little quantity of the extracts the solution was divided into 2 test tubes.

Mayer's test: In the first portion of the filtrate, 2 drops of Mayer's reagent (Potassium Mercuric Iodide solution) was added. The Formation of a yellow coloured precipitate indicates the presence of alkaloids.

Wagner's test: To the second portion of the filtrate, 2 drops of Wagner's reagent (Iodine in Potassium Iodide) were added. The formation of brown-reddish precipitate indicates the presence of alkaloids.

\section{Test for cardiac glycosides}

Keller-killiani's test: Small quantity of the extract was diluted with sufficient water and $1 \mathrm{ml}$ of strong lead sub acetate solution was added to precipitate pigments, which were filtered off. The filtrate obtained was shaken with an equal volume of chloroform and allowed to separate into two layers. The chloroform layer was removed and evaporated to dryness over a water bath. The residue was dissolved in sufficient ferric chloride in glacial acetic acid, left for a minute and then transferred to a dry test tube. Few drops of conc. Sulphuric acid were added by the wall of the test tube. On standing a brown colour at the interphase (due to deoxy sugars) and a pale green colour in the upper layer (due to steroidal nucleus) served as a preliminary test for digitoxose (Brain and Turner, 1975).

\section{Test for carbohydrates}

The extract was dissolved individually in sufficient distilled water and filtered. The filtrates were used to test for the presence of carbohydrates.

Filtrates were treated with 2 drops of alcoholic and napthol solution in a test tube. The formation of the violet ring at the inter phase indicates the presence of carbohydrates.

A $2 \mathrm{ml}$ of Benedict's reagent $\left(\mathrm{CuSO}_{4}\right)$ was added to the small quantity of the sample, the solution is the heated in a boiling water bath for $3-5 \mathrm{~min}$. The formation of orange colour indicates the presence of carbohydrates.

Test for flavonoids

Shinoda test: The extract was dissolved in $2 \mathrm{mls}$ of distilled water and heated, four drops concentrated Hydrochloric acid were then added followed by some magnesium chips, immediate appearance of orange colour denotes flavones, red crimson colour denotes flavonoids.

Ferric chloride test: Small quantity of extract was diluted to a ratio of 1:4 with distilled water and few drops of ferric chloride solution were added in green or blue colour indicates the presence of a phenolic nucleus (Brain and Turner, 1975).

Alkaline reagent $(\mathrm{NaOH})$ test: The extract was treated with few drops of sodium hydroxide solution. The formation of intense yellow colour which becomes colourless on the addition of dilute acid indicates the presence of flavonoids (Trease and Evans, 2008).

\section{Test for Anthraquinone}

Borntrager's test: The extract was concentrated and shaken with $5 \mathrm{ml}$ of $25 \%$ of ammonia solution. A cherry-red colour of the alkaline solution indicates emodin in an oxidized form (Trease and Evans, 2008).

\section{Test for Saponins}

Frothing test: The extract was diluted with a sufficient volume of water and shaken in a test tube for about $5 \mathrm{~min}$. The occurrence of honey combs froth which lasts for about 45min, indicates the presence of saponins (Sofowora, 1984).

\section{Test for phytosterols/ Triterpenoids}

Salkowskis's test: The extract was treated with chloroform and filtered. The filtrates were treated with few drops of concentrated Sulphuric acid. The test tube was shaken and allowed to stand the appearance of golden yellow colour indicates the presence of triterpenes. 
Libermann Burchaard's test: The extract was treated with chloroform and filtered. The filtrate was treated with few drops of acetic anhydride boiled and cooled. Concentrated Sulphuric acid was added in a slant position of test tube. The formation of brown-ring at the interphase indicates the presence of phytosterols (Sofowora, 1984).

\section{ACUTE TOXICITY}

Sub-acute oral toxicity test was performed according to the organization of Economic Co-operation and Development (OECD) guideline 407 for testing of chemicals.

The animals were divided into three experimental groups $(\mathrm{n}=5)$ animals/group. Three different doses of Tokar sha concoction $(250,500,1000 \mathrm{mg} / \mathrm{kg})$ were administered orally for 5 consecutive days.

All mice were then allowed free access to food and water and were observed for behavioral and physiological variation initially, then continuously for $30 \mathrm{~min} 1$ hour. The monitoring of the parameters commenced immediately after administering the extract, for signs of toxicity, which included but were not limited to paw-licking, motor activity, tremors, convulsions, posture, spasticity, opisthotonicity, ataxia, sensations, piloerection, ptosis, lacrimation, exophthalmos, salivation, diarrhoea, writhing, skin colour, respiratory rate and mortality.

\section{ANTIBACTERIAL ASSAY OF TOKAR SHA}

Screening of tokar sha for Antibacterial activity

The Antibacterial activity of the aqueous solution of tokar sha were determined using the agar well diffusion method as described by (Boakye- Yiadom,1979) and (Boyanova et $a l ., 2005)$. Inocula of the isolates were standardized by picking a discrete colony and emulsify it in normal saline to a turbidity equivalent to that of $0.5 \mathrm{McF}$ arland's standard. A $7 \mathrm{~mm}$ sterile stainless steel cork borer was used to make wells on the plates. The holes were individually filled with $20 \mathrm{mg} / \mathrm{ml}, 25 \mathrm{mg} / \mathrm{ml}, 30 \mathrm{mg} / \mathrm{ml}$ and $35 \mathrm{mg} / \mathrm{ml}$ of the aqueous solution of tokar sha using $2 \mathrm{ml}$ syringe and each well was appropriately labeled. Amoxicillin disc $10 \mu \mathrm{g}$ was used as a positive control. The plates were left to stand for 2 hours at room temperature to allow diffusion of the solution and were then incubated at $37^{\circ} \mathrm{C}$ for 24 hours. The assay was done in duplicate for each sample on the four (4) organisms. Results were read by measuring the diameters zone of inhibition $(\mathrm{mm})$ around the wells and the mean value for each was determined.

\section{Determination of Minimum Inhibitory Concentration}

The minimum inhibitory concentrations of aqueous solution of tokar sha were determined using the macro broth dilution method as described by (NCCLS, 2000). Nine sets of test tubes each containing sterile broth $(5 \mathrm{ml})$ were used. A $70 \mathrm{mg} / \mathrm{ml}$ stock solution of aqueous solution of tokar sha was prepared in distilled water and two- fold serial dilution in the nutrient broth was carried out to give concentrating of $35 \mathrm{mg} / \mathrm{ml}, 17.50 \mathrm{mg} / \mathrm{ml}, 8.75 \mathrm{mg} / \mathrm{ml}, 4.38 \mathrm{mg} / \mathrm{ml}, 2.19$ $\mathrm{mg} / \mathrm{ml}, 1.09 \mathrm{mg} / \mathrm{ml}, 0.55 \mathrm{mg} / \mathrm{ml}, 0.27 \mathrm{mg} / \mathrm{ml}$ and 0.14 $\mathrm{mg} / \mathrm{ml}$ and 2 test tube are used were one is used as growth control and the other for sterility test. Each set was individually inoculated with a standardized suspension of Bacillus cereus and Escherichia coli except the one for sterility test. The tubes were incubated at $37^{\circ} \mathrm{C}$ for 24 hours and examined for visible bacterial growth as evidenced by turbidity. The lowest concentration that not supports growth was taken as the minimum inhibitory concentration.

Determination of Minimum Bactericidal concentration The minimum Bactericidal concentration of an aqueous solution of tokar sha on the two bacteria species was determined by sub-culturing the test dilution from the minimum inhibitory concentration where no visible growth was seen as described by (NCCLS, 2000). A sterile inoculating loop was used to streak the different test dilutions onto the fresh nutrient agar previously prepared. Each test was marked into the quadrant and a set of individual dilutions of the solution on the different organisms were streaked onto separate plates giving a total of two plates. The plates were incubated upside down at $37^{\circ} \mathrm{C}$ for 34 hours. The minimum Bacterial concentration was determined by where there was no visible growth on the plates.

\section{RESULTS}

\section{PHYTOCHEMICAL SCREENING OF TOKAR SHA}

The result of phytochemical screening of Tokar Sha obtained revealed the presence of some primary and secondary metabolites including; carbohydrates, oils, cardiac glycosides, saponins and phytosterols as presented in table 1 .

Table 1: Result of Phytochemical Screening of Tokar sha

\begin{tabular}{lc}
\hline Constituents & Results \\
\hline Alkaloids & - \\
Carbohydrate & + \\
Cardiac glycosides & + \\
Tannins & - \\
Saponins & + \\
Phytosterols/triterpenoids & + \\
Flavonoids & - \\
Oils & + \\
Anthraquinones & - \\
\hline Keys: - = Negative, $+=$ Positive &
\end{tabular}


ACUTE TOXICITY STUDIES OF TOKAR SHA USING LIMIT DOSE TEST

No death was recorded in the mice orally administered with 5000mg doses of Tokar sha. The concoction was well tolerated by the mice without any overt signs of toxicity. The result is shown in table 2.

Table 2: Result of Oral acute toxicity studies of Tokar sha in Mice

\begin{tabular}{lcc}
\hline DOSE $(\mathbf{m g} / \mathbf{k g})$ & NUMBER OF ANIMALS USED & \% MORTALITY \\
\hline 5000 & $0 / 1$ & 0 \\
5000 & $0 / 1$ & 0 \\
5000 & $0 / 1$ & 0 \\
5000 & $0 / 1$ & 0 \\
5000 & $0 / 1$ & 0 \\
\hline
\end{tabular}

\section{ANTIBACTERIAL ACTIVITY OF TOKAR SHA}

The results of Antibacterial screening show that the aqueous solution of tokar sha has activity on Escherichia coli and Bacillus cereus but it has no activity on Staphylococcus aureus and Salmonella typhi. The zone of inhibition ranges from $12 \mathrm{~mm}$ to $25 \mathrm{~mm}$ with Escherichia coli having the highest zone of inhibition of $25 \mathrm{~mm}$ and Bacillus cereus with $12 \mathrm{~mm}$ as the lowest as presented in Tables 3 and 4 respectively.

Table 3: Antibacterial activity of Tokar Sha on $S$. aureus, B. cereus, E. coli and $S$. typhi

\begin{tabular}{lcccc}
\hline \multicolumn{4}{c}{ Mean diameter zone of inhibition $(\mathrm{mm})$} \\
ORGANISMS & S. aureus & B. cereus & E.coli & S. typhi \\
\hline CONCENTRATION $(\mathrm{mg} / \mathrm{ml})$ & & & & \\
35 & - & 20 & 25 & - \\
30 & - & 14 & 23 & - \\
25 & - & 12 & 23 & - \\
20 & - & - & 21 & - \\
\hline
\end{tabular}

KEY: - = No zone of inhibition

Table 4: Diameter zone of inhibition of Standard Antibiotics (Amoxicillin) on S. aureus, B. cereus, $E$. coli and $S$. typhi

\begin{tabular}{lllll}
\hline & \multicolumn{4}{c}{ Mean diameter zone of inhibition $(\mathrm{mm})$} \\
ORGANISMS & S. aureus & B. cereus & E.coli & S. typhi \\
\hline CONCENTRATION $(\mu \mathrm{g} / \mathrm{ml})$ & & 42 & 10 & 15 \\
10 & 36 & 42 & & \\
\hline
\end{tabular}




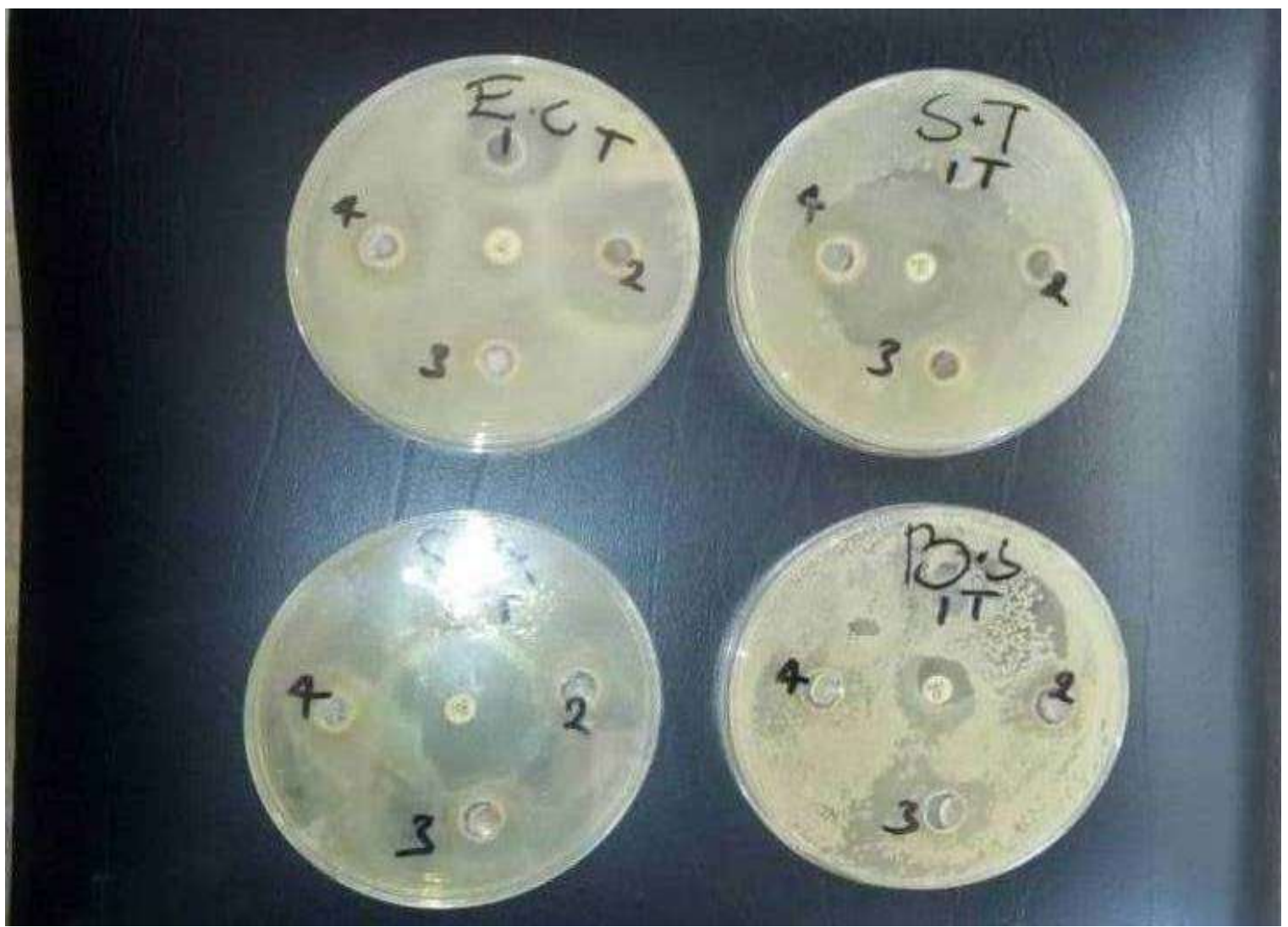

Fig 2: Antibacterial screening of tokar sha on S. aureus, B. cereus, E. coli and S. typhi using Amoxicillin disc as Standard Antibiotics

\section{MINIMUM INHIBITORY CONCENTRATION (MIC)}

The minimum inhibitory concentration (MIC) against the two organisms that are susceptible to Tokar sha was determined and found to be $35 \mathrm{mg} / \mathrm{ml}$ being the lowest concentration for both Escherichia coli and Bacillus cereus whereby, the remaining concentration ranges from $17.5 \mathrm{mg} / \mathrm{ml}$ to $0.14 \mathrm{mg} / \mathrm{ml}$ has the growth of organisms as shown in the Table 5 .

Table 5: Minimum Inhibitory Concentration of tokar sha on B. cereus and E. coli

\begin{tabular}{lcc}
\hline ORGANISMS & B. cereus & E. coli \\
\hline Aqueous solution of Tokar Sha $(\mathrm{mg} / \mathrm{ml})$ & 35 & 35
\end{tabular}

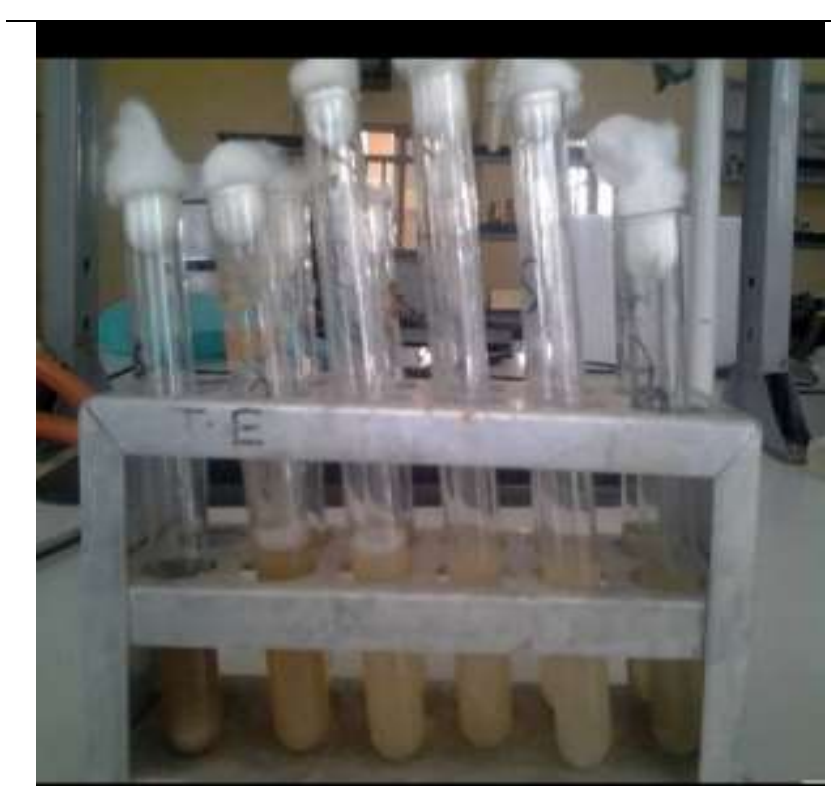

Fig. 3A: MIC of E. coli 


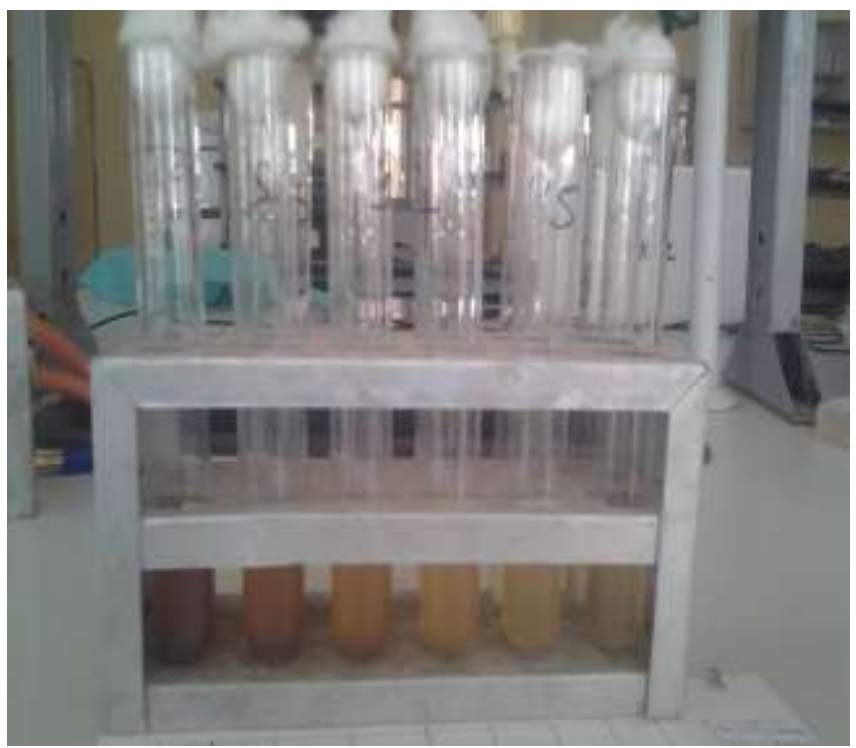

Fig. 3B: MIC of B. cereus

\section{MINIMUM BACTERICIDAL CONCENTRATION (MBC)}

The Minimum Bactericidal Concentration (MBC) results (Table 6) shows that the aqueous solution of tokar sha has the lowest $\mathrm{MBC}$ at $35 \mathrm{mg} / \mathrm{ml}$ for both Escherichia coli and Bacillus cereus whereas the remaining concentration ranges from $17.5 \mathrm{mg} / \mathrm{ml}$ to $0.14 \mathrm{mg} / \mathrm{ml}$ there is no inhibition of Bacterial growth.

\section{DISCUSSIONS}

The phytochemical screening results obtained show that tokar sha contains a variety of primary and secondary metabolites namely; carbohydrate, cardiac glycosides, phytosterols, saponins, and oils. Which contribute greatly to its diverse activity including antibacterial activity.

In screening natural products for pharmacological activity, assessment and evaluation of the toxic characteristics of a natural product extract, fraction, or compound are usually initial steps taken. In this study, Tokar sha at doses up to $5000 \mathrm{mg} / \mathrm{kg}$ had no treatment-related signs of toxicity or mortality in any of the animals tested during 24 hours of observation. The LD50 of Tokar sha was estimated to be more than $5000 \mathrm{mg} / \mathrm{kg}$. Therefore, Tokar sha can be categorized as highly safe extracts since substances possessing LD50 higher than $5000 \mathrm{mg} / \mathrm{kg}$ body weight are non-toxic (Buck et al., 1976).

The Antibacterial screening results show that tokar sha has activity on two of the test organisms (Escherichia coli and Bacillus cereus) while the other two organisms (Staphylococcus aureus and Salmonella typhi) are found resistant. The highest zone of inhibition been $25 \mathrm{~mm}$ and 20 $\mathrm{mm}$ for E. coli and B. cereus at $35 \mathrm{mg} / \mathrm{ml}$ and the lowest zone of inhibition $12 \mathrm{~mm}$ at $25 \mathrm{mg} / \mathrm{ml}$ for Bacillus cereus, tokar sha shows better Antibacterial activity on E. coli than $B$. cereus, because $B$. cereus has no zone of inhibition at 20 $\mathrm{mg} / \mathrm{ml}$ concentration whereas $E$. coli has $21 \mathrm{~mm}$ zone of inhibition. Thus it is seen that the zone of inhibition in each organism increases with an increase in concentration making the antibacterial effect to be dose-dependent. Antibacterial activity seen can be because the cell walls of B. cereus which is a gram-positive bacterium are made up of main peptidoglycan. Peptidoglycan is found to be distorted by long-chain fatty acids that are found in palm oil an active ingredient in tokar sha. The activity against B. cereus and $E$. coli therefore, could be attributable to the palm oil present in the tokar sha (Ugbogu, 2006). Ugbogu, (2006) reported that palm oil has an inhibitory effect on B. cereus and E. coli. The major fatty acids in palm oil used for the production of tokar sha are lauric acid, myristic acid and oleic acid. Certain fatty acids (medium-chain saturates) and their derivatives have adverse effects on various microorganisms (Kabara, 1978).

Tokar sha also contain saponins as already seen in the phytochemical analysis result and since saponin are known to be a detergent-like substance having Antibacterial activity which disturbs the permeability of the bacterial outer membrane by interacting with lipid. A part of Proteus lipopolysaccharide LPS that is about $90 \%$ of the surface of naturally cholesterol - free gram-negative bacteria cell-wall (Arabski et al., 2009). There was no observed inhibitory effect on $S$. aureus and S. typhi by tokar sha at all concentrations used, this resistance can be said to be due to chromosomal mutation that lower the permeability of the agent or acquisition of resistant (R) plasmids and transposons (Arora, 2004).

The MIC and MBC results of both susceptible organisms (Escherichia coli and Bacillus cereus) were found at a concentration of $35 \mathrm{mg} / \mathrm{ml}$. Although there was a record of the zone of inhibition at lower concentrations $(20 \mathrm{mg} / \mathrm{ml}$ and $25 \mathrm{mg} / \mathrm{ml}$ ) than this from antibacterial screening. Thus, because the MBC value was in all cases the same as in MIC value, it can be deduced that tokar sha shows only bactericidal activity with no bacteriostatic activity. 


\section{CONCLUSIONS}

In this study, it was revealed that tokar sha exhibited antibacterial activity against the test organisms Escherichia coli and Bacillus cereus providing a support on its ethnomedicinal uses in treating piles, stomach cramps and other entero-infections.

It is recommended that further studies should be conducted on tokar sha to exploit and confirm other ethnomedicinal uses that had been attributed to tokar sha so that it can be produced industrially employing hygienic standards.

\section{REFERENCES}

Adebolu, T. T. and Oladimeji, S. A. (2005). Antimicrobial Activity of Leaf Extracts of Ocimum Gratissimum on Selected Diarrhoea Causing Bacteria in Southwestern Nigeria". African Journal of Biotechnology 4 : (7) 682-684.

Arabski, M., Wasik, S., Dworecki, K. and Kaca, W. (2009). Laser interferometric and cultivation methods for measurement of colistin/ampicilin and saponin interactions with smooth and rough of Proteus mirabilis lipopolysaccharides and cells. Journal of Microbiological Methods, vol. 77, no. 2, pp. 178-183.

Arora (2004). Textbook of Microbiology. Satish Kumar publishers, India.

Babayi, H., Kolo, I., Okogun, J. I. and Ijah, U. J. (2004). The Antimicrobial Activities of Methanolic Extracts of Eucalyptus Camaldunensis and Terminalia Catappa Against Some Pathogenic Microorganisms. Biokemistri; 16(2):106111.

Boakye-Yiadom (1979). Antimicrobial Properties of Some West African Medicinal Plants and Antimicrobial Activity of Aqueous Extract of Cryptolepsis Sangumolenta. Quarterly Journal of Crude Drug Research, 17(2):78-80.

Boyanova, L. (2005). Activity of Bulgaris Propolis against 94 Helicobacter pylori strains in Vitro by Agar-Well Diffusion, Agar Dilution and Disc Diffusion Methods. Journal of Medical Microbiology, 54:481-83.

Brain, K. and Turner, T., (1975). The Practical Evaluation of Phytopharmaceuticals. Great Britain: John Wrightan and Sons Ltd, P. 2.

Buck, W.B., Osweiter, G.D. and Van Gelder, A. G. (1976). Clinical and diagnostic Veterinary Toxicology. Iowa: Kendall/hunt Publishing Co; P.5211.

Cohen, M. L. (1992). Epidemiology of Drug Resistance". Implications for a Post-Antimicrobial Era. Science, $257:$ ( 5073) 1050-1055.

Cowan, M. M. (1999). Plants Products as Antimicrobial Agents. Clinical Microbiology Review. 12:564-582.
Elvin-Lewis, M. (2001). Should we be Concerned about Herbal Remedies. Journal of Ethno pharmacology, 75 : (23) $141-164$.

Erdogrul. O. T. (2002). Antibacterial Activity of Some Plant Extracts Used in Folk Medicine. Pharmaceutical Biology; 40:269-273.

Kabara, J. J. (1978). Health Oils from the Tree of Life, In Pharmacological Effects of Lipids. AOCS Press London. pp. 624-629.

Kafaru, E. (1994). Immense Help from Nature`s Workshop. Elika Health Services Ltd., Academic Press Plc. Lagos, Nigeria: 1-27.

Naqvi, S. A. H., Khan, M.S.Y. and Vohora, S. B. (1991). Antibacterial, Antifungal and Anthelmintic Investigations on Indian Medicinal Plants (Fitoterapia). Journal of Indian Medicine,6 :(2) 221-228.

Nascimento, G. G. F., Freitas, J. P. C. and Silva, G.L. (2000). Antibacterial Activity of Plant Extracts and Phytochemicals on Antibiotic-Resistant Bacteria”. Brazilian Journal of Microbiology 31: 247-256.

NCCLS, (2000). Methods for Dilution Antimicrobial Susceptibility Tests for Bacteria That Grow Aerobically: Approved Stardard. 5th Ed. Wayne, PA USA.

Osowole, O., Ajaiyeoba, E., Bolaji, O., Akinboye, D., Fawole, O., Gbotosho, G. and Oduola, A. A. (2005). Survey of Treatment Practices for Febrile Illnesses among Traditional Healers in The Nigerian Middle Belt Zone. African Journal of Traditional and Complimentary/ Alternative Medicine. 2:337-34412.

Owolabi, O. J., Omogbai, E. K. I. and Obasuyi, O. (2007). Antifungal and Antibacterial Activities of the Ethanolic and Aqueous Extract of Kigella Africana (Bignoniaceae) Stem Bark. African Journal of Biotechnology, 6 : (14) 1677-1680.

Rios, J. L. and Recio, M. C. (2005). Medicinal Plants and Antimicrobial Activity. Journal of Ethno pharmacology. 100: $80-84$.

Rodders, J., Speedie, M., Tyler, V. (1996). Pharmacognosy and Pharmaco-Biotecknology. Baltimore: Williams and Wilkins.7-12.

Shibata, H., Kondo, K., Katsuyama, R., Kawazoe, K., Sato, Y., Murakami, K., Takaishi, Y., Arakaki, N. and Higuti, T. (2005). Alkyl Gallates, Intensifiers of B-Lactam Susceptibility in Methicillin-Resistant Staphylococcus Aureus Antimicrobial Agents Chemotherapy. 49(2):549555. 
Sofowora, E. A. (1993). Medicinal plants and traditional remedies in Africa. University of Ife Press, Nigeria.

Trease, G. E. and Evans, W.C. (2009). Textbook of Pharmacognosy, $16^{\text {th }}(\mathrm{Ed})$ BalliersTindall, London.

Ugbogu, O. C. (2006). Lauric Acid Content and Inhibitory Effect of Palm Kernel Oil on Two Bacterial Isolates and C. Albicans. African Journal of Biotechnology 5(11):10451047.

Yadesa, T.M., Gudina, E.K. and Angamo, M.T. (2015). Antimicrobial Use-Related Problems and Predictors among Hospitalized Medical In-Patients in Southwest Ethiopia: Prospective Observational Study. PLoS ONE 10(12): e0138385. doi:10.1371/journal. pone. 013838 cited appropriately. 